\title{
TTR
}

Traduction, terminologie, re?daction

\section{Rosanna Masiola Rosini. La traduzione è servita ovvero Food for Thought. Trieste, Università di Trieste, 2004, 590 p.}

\section{Corrado Federici}

Volume 19, numéro 1, 1er semestre 2006

Figures du traducteur/Figures du traduire I

Figures of Translators/Figures of Translation I

URI : https://id.erudit.org/iderudit/016670ar

DOI : https://doi.org/10.7202/016670ar

Aller au sommaire du numéro

\section{Éditeur(s)}

Association canadienne de traductologie

ISSN

0835-8443 (imprimé)

1708-2188 (numérique)

Découvrir la revue

Citer ce compte rendu

Federici, C. (2006). Compte rendu de [Rosanna Masiola Rosini. La traduzione è servita ovvero Food for Thought. Trieste, Università di Trieste, 2004, 590 p.] TTR, 19(1), 230-232. https://doi.org/10.7202/016670ar

Tous droits réservés () TTR: traduction, terminologie, rédaction Les auteurs, 2007
Ce document est protégé par la loi sur le droit d'auteur. L'utilisation des services d'Érudit (y compris la reproduction) est assujettie à sa politique d'utilisation que vous pouvez consulter en ligne.

https://apropos.erudit.org/fr/usagers/politique-dutilisation/ 
contenterai donc, en attendant mieux, de ce rôle de trait d'union, irisé et aérien, qui me convient à merveille » (p. 39).

Nour Dib

Université McGill

\section{Références}

BERMAN, Antoine (1989). "La traduction et ses discours ». META, XXXIV, 4, pp. 672-679.

\section{Rosanna Masiola Rosini. La traduzione è servita ovvero Food for Thought. Trieste, Università di Trieste, 2004, 590 p.}

The University of Trieste, Italy, in which the Advanced School of Modern Languages for Interpreters and Translators is homed, offers the reader of Masiola Rosini's book, which translates literally as Translation is Served or Food for Thought, the first volume of a planned trilogy entitled, Tematiche in traduzione (Thematics in Translation). The second volume is to be Fashion in Translation: $\mathrm{La}$ moda nel tradurre, and the third Perle di traduzione (literally, Pearls of Translation): Lust in Translation. Masiola Rosini is the author of three other books on translation theory and practice, two written in Italian and one in German. She has also contributed the chapter, "Marianna Florenzi: la 'belle marquise'. Volage en quête de fidélité absolue," to the anthology Portraits de traductrices, edited by Jean Delisle (Ottawa, Presses Universitaires, 2002), which deals with the figure of women translators in history.

As the general heading of the publication project suggests, the organizing principle in this interesting and timely series of publications is thematic. Writing in Italian, the author examines more than 100 texts, from ancient to modern in several source languages including English, French, Italian, German, Spanish, and Swedish, in which terms and expressions pertaining to the theme of food appear in both literal and metaphorical form. These texts are drawn from travel literature, fables, adventure stories, Italian-American writing, cookbooks, or menus and sweep across millennia and virtually the globe, ranging as they do from the Bible, Pliny, Plutarch, Rabelais, Dickens, Mann, Proust, and Swift, to Tolkien, Calvino, Eco, and Rawlings. While much of the book provides close linguistic analysis of passages (from one or two 
sentences to short paragraphs) taken from the sources indicated above, several pages are devoted to the close reading of Italian translations of Charles Dickens' Oliver Twist and David Copperfield, and Mark Twain's Adventures of Tom Sawyer, as well as to English translations of Carlo Collodi's Pinocchio.

In addition, the 30 chapters, divided into 4 parts, correspond to the themes or cultural content of the descriptive passages; these include such titles as "Viaggiatori in Italia" (Travellers to Italy), "Fasti e crudità” (Pomp and Rawness), "Fiesta, amore e fantasia," (Fiesta, Love and Fantasy), "Domini e generi coloniali," (Dominions and Colonial Genres), "Foodscapes e Topofilia," (Foodscapes and Topophilia), "Rappresentazioni maschili" (Male Representations), "Il cibo della provvidenza" (The Food of Providence) [not Rhode Island], and "Anglo-ebraismo: i cibi proibiti e l'assimilazione" (Anglo-Hebrewism: Prohibited Foods and Assimilation). Although there is, as might be expected, a degree of overlap and repetition with respect to the rubrics selected, the reader will find coherence and clarity of exposition.

In the introductory chapter, Masioli Rosini sets out the theoretical parameters of her research in terms of the notion of "topicalization" citing, for example, the definition provided by Robert de Beaugrande: “A topic (in some sources also called 'theme,' 'main idea,' 'macrostructure,' or 'superordinate proposition') acts as a control centre to steer the evolution of the text-world model” (p. 8). The author then proceeds to examine the translation of the texts identified above into the target languages of Italian and English, with the exception of one or two excerpts in which the TL is Spanish or French. She brings to bear her extensive knowledge of Translation Theory and current literature on Thematics. The volume, as a result, is impressive in scope, richly illustrated, and linguistically sophisticated.

The findings in this meticulous, scholarly study predictably brings to the fore issues or problems with which translators and translation theorists are familiar, such issues as untranslatability, translation loss, cultural specificity, foreignization, and domestication. As well, the author identifies the many strategies applied by translators, with varying degrees of success, to render texts from the SL, including the use of loanwords, calques, semantic equivalents, modulation, adaptation, and compensation. She points out two regrettable tendencies: the loss of linguistic precision, since in many cases there is no equivalent for a specific regional food or for the manner in which 
that food may be or may have been prepared, and the loss of symbolic and connotative meaning, as the prevailing trend in translation has been and continues to be toward domestication of the foreign, despite the urgings of critics such as Lawrence Venuti.

Beyond this, Masioli Rosini's principal contribution to the field is her discovery, in this encyclopedic collection of translation samples, of a polarity of sensibilities: Mediterranean Catholic culture on one side, and Nordic or Anglo-American Protestant culture on the other. Examination of several representative passages from a variety of SL texts leads her to draw such conclusions as: "Non abbiamo proverbi come questo (We do not have proverbs like): 'God sends the meat, the Devil sends the cook"” (p. 27) and "Non vedremo mai un piatto di spaghetti o una pizza su una tomba, in un racconto di bambini" (We will never see a dish of spaghetti or a pizza on a tomb, in children's literature, p. 27). The "we" to whom she refers is, of course, Italian, and by extension Mediterranean, society and culture.

As the author herself claims, the book has concrete applicability to the teaching of translation in general, Italian language pedagogy in particular, and comparative literature. She adds that it is also possible to design cultural studies or interdisciplinary courses related to the consumption and advertisement of food, as well as to images, iconography, and the diffusion of loanwords. It must be said, however, that her suggestions fit best in an Italian-English context and are more difficult to visualize in other language environments.

Despite the foregoing qualification, this insightful and often amusing volume is much more than "food for thought." It is a veritable feast and an invaluable resource for Italianists, translators, and theorists of translation. 